\title{
Progressive Practices of Government Management in Preschool Teachers Professional Training in Western European Countries
}

\author{
Nataliia I. Melnyk ${ }^{1, *}$, Valentyna M. Vertuhina ${ }^{2}$, Liubov V. Artemova ${ }^{3}$, Oksana O. Avramenko ${ }^{4}$, \\ Nataliia M. Pavlushchenko ${ }^{5}$
}

\begin{abstract}
${ }^{1}$ Department of Foreign Philology, Faculty of Linguistics and Social Communications, National Aviation University, Ukraine ${ }^{2}$ Department of Preschool Education, Pedagogical Institute, Borys Grinchenko Kyiv University, Ukraine

${ }^{3}$ Department of Preschool Pedagogy and Psychology, Oleksandr Dovzhenko Hlukhiv National Pedagogical University, Ukraine

${ }^{4}$ Department of Psychology and Pedagogy of Child Development, Faculty of Preschool Education, Pavlo Tychyna Uman State Pedagogical University, Ukraine

${ }^{5}$ Department of Preschool and Primary Education, Educational and Scientific Institute of Pedagogy and Psychology, A. S. Makarenko Sumy State Pedagogical University, Ukraine
\end{abstract}

Received June 19, 2020; Revised August 13, 2020; Accepted August 25, 2020

Cite This Paper in the following Citation Styles

(a): [1] Nataliia I. Melnyk, Valentyna M. Vertuhina, Liubov V. Artemova, Oksana O. Avramenko, Nataliia M. Pavlushchenko, "Progressive Practices of Government management in Preschool Teachers Professional Training in Western European Countries," Universal Journal of Educational Research, Vol. 8, No. 10, pp. 4591-4602, 2020. DOI: 10.13189/ujer.2020.081027.

(b): Nataliia I. Melnyk, Valentyna M. Vertuhina, Liubov V. Artemova, Oksana O. Avramenko, Nataliia M. Pavlushchenko (2020). Progressive Practices of Government management in Preschool Teachers Professional Training in Western European Countries. Universal Journal of Educational Research, 8(10), 4591-4602. DOI: 10.13189/ujer.2020.081027.

Copyright $(2020$ by authors, all rights reserved. Authors agree that this article remains permanently open access under the terms of the Creative Commons Attribution License 4.0 International License

\begin{abstract}
Government management plays an important part in each branch of social activity and influence on its quality as well. It has a very essential importance in the sphere of professional education. The governmental initiations in teachers' professional education have a great influence not only on quality but also on standards and qualification and models of getting the profession as well. The purpose of this article is to show how the governmental management initiations in preschool teaching professional education make the profit for its quality, development, and improvement. The governmental management of preschool teachers' professional training, qualifications requirements to preschool teachers is important for the standardisation of qualification framework of preschool teachers and preschool teachers' professional education system functioning in different European countries are presented as progressive practices for effective preschool teachers' professional training. These practices of government management are analysed from the perceptivity of implementation into Ukrainian system of pedagogical
\end{abstract}

education. The investigation of the progressive practices of preschool teachers' professional training in Western European countries allowed us to distinguish three directions of this experience implementation into Ukrainian higher pedagogical education system. The directions are divided into the levels such as improvement: governmental, institutional and procedural. The studding of progressive European experience also forms the basis for the development of The New Conception of preschool teachers' professional training in Ukraine, thus the authors emphasise the necessity of systemic comparative investigation of different aspects of this experience and point out the organisational and methods aspect require the comparative analysis, which will be the next step of the complex study.

Keywords Educational Policy, Governmental Management, Preschool Teachers' Professional Education System Functioning, Professional Teachers' Education and Training, Qualifications Requirements, Western European Countries Experience Implementation 


\section{Introduction}

The general trend in our times toward increasing intervention by the state in economic affairs has led to a concentration of attention and dispute on the areas where new intervention is proposed and to an acceptance of whatever intervention has so far occurred as natural and unchangeable. The current pause, perhaps reversal, in the trend toward collectivism offers an opportunity to re-examine the existing activities of government and to make a fresh assessment of the activities that are and those that are not justified. This paper attempts such a re-examination for education.

Education is today largely paid for and almost entirely administered by governmental bodies or non-profit institutions. This situation has developed gradually and is now taken so much for granted that little explicit attention is any longer directed to the reasons for the special treatment of education even in countries that are predominantly free enterprise in organization and philosophy. The result has been an indiscriminate extension of governmental responsibility and its influence on the quality and. The role assigned to the effective practices of government management in any particular field depends, of course, on the principles accepted for the organization of society in general [1]. The interest and the subject of our investigation are the progressive practices of government management of preschool teachers' professional training in Western European countries.

The main idea of the investigation presented in this issue is to investigate preschool teachers' professional training practices in Western European countries from the perceptivity of its implementation into Ukrainian higher pedagogical education as the country from post-SSR region. The conclusions and results of the issue will be useful for the similar countries which eager to develop the qualitative and according to European standards system of pedagogical training. In order to give the qualitative characteristic of positive government practices in preschool teachers' professional training in Western European countries, we have overlapped our choice by only three European countries (German, Breat Britain and France). The choice is also connected with that these countries are the primaries which initiated the process of European countries' educational and professional system integration [2]. Until the early 1990s most eastern European education systems followed the old Soviet model [3]. In Europe, many countries were influenced by the British, German, and French systems, but there were numerous variations, some of which are treated here [4].

Thus, the aim of the article is to demonstrate how positive experience of preschool teachers' professional training in leading German, English and French universities could be implemented into the pedagogical educational system of Eastern post-soviet countries.

The task, which was realized through investigation, laid in the staged-solving comparative analysis of the different aspects of preschool teachers' professional training. These aspects included:

- describing the governmental management of professional preschool teachers' training in Western European countries (Germany, France, Great Britain) for distinguishing the progressive experience in this aspect;

- $\quad$ studding qualifications requirements to preschool teachers in western European countries which is important for the standardisation of qualification framework of preschool teachers in Ukraine or other Eastern European countries;

- distinguishing the main characteristics of modern preschool teachers' professional education system functioning in Western European countries, which will help to point out the most progressive ideas of the Western European countries' experience in preschool teachers' professional training;

- distinguishing the perceptivity of Western European countries experience in preschool teachers' professional training into Ukrainian system of pedagogical education.

\section{Materials and Methods}

In the process of analytically-comparative investigation it's vital to take into account the methodological approaches of preschool teachers' professional training in the EU countries, thus the research referred to a set of interrelated groups of approaches identified by [5], [6]: basic (dialectic, systemic and integral, systemic and historical, synergetic), paradigmatic (cultural, axiological, paradigmatic) and instrumental (comparative, hermeneutical, parametric, interval, narrative and thesaurus-based). The instrumental approach to identifying models and peculiarities of preschool teachers' professional training in the Western EU countries was defined as the main one.

The key specific method of the research is comparative pedagogical analysis, which is an integrated method encompassing a set of research tools aimed at identifying common and distinct in the pedagogical objects being compared [7]. This method is one of the effective means of comparative analysis that is a binary comparison or binary analysis [8], which ensures "a profound and detailed comparison of the two countries' education systems, which correlates the problems of education with the broad historical cultural and socio-political context [9]. In [9] was identified two types of binary comparisons as follows: the first type - a comparison of the national and foreign general education systems; the second type - a comparison of two foreign countries' education systems). 
Defining approaches and principles is an important and integral step of comparative studies, however, it is equally important to identify a set of methods that ensure the implementation of this study. In addition to the mentioned approaches of the study, it should be emphasized that, as in any type of research work, the study used general scientific methods such as theoretical analysis and synthesis, concretization, analogy, modelling, generalization, systematization, classification, allowing to allocate a key problem, to form the scientific apparatus and the concept of research, to reveal essential characteristics, leading tendencies and regularities of development of pedagogical phenomena, experience on the research problem, etc.

A necessary condition for a qualitative comparative study is the collection and primary processing of the actual material, which is carried out using various methods. Empirical methods such as observation, interviews (oral - interview and written - questionnaires, testing), interviews provided a wide range of views on the study of different groups of respondents: preschool teachers, administrative staff of preschools in Ukraine and Western Europe, teachers of higher educational institutions, trainers of professional pedagogical courses, employees and listeners of the sphere of professional training, heads of higher educational institutions and centres of professional development and training, etc.

Comparative pedagogical research is impossible without the use of the method of studying the actual material, for e.g. without the study of normative documents, pedagogical documentation, educational and methodical literature, statistical data. The important factual material for the knowledge and comparison of pedagogical objects and phenomena is contained in monographic studies, publications of periodicals, collections of scientific papers and conference proceedings, the Internet, etc.

One of the most important instrumental methods was the method of binary comparison of pedagogical practices and particular organizational elements in the training of preschool teachers. During the research period (2012-2020) in the context of private trips and internships at universities of Germany, France, Austria, Sweden and Bulgaria, a representative of the authors' team carried out direct observation of the peculiarities of the organization of professional training of educators in the countries selected for analysis; conversations were held with colleagues, students, administration, etc.

Based on different approaches (dialectical, system-holistic, system-historical, synergetic, culturological, axiological, paradigmatic, acmeological, comparative, hermeneutic, parametric, interval, narrative and thesaurus) which contained different systematic methods (observation, interviews, collection and primary processing of the actual material, method of studying the actual material, method of binary comparison etc.) the investigation of preschool teachers pedagogical education and training have been analysed thoroughly, as each of the approaches involved a deep understanding of the phenomenon of preschool teachers professional training.

\section{Results and Discussions}

\subsection{Governmental Management of Professional Preschool Teachers' Education in Western European Countries (Germany, France, Great Britain)}

\subsubsection{Germany}

The modern system of vocational training for preschool teachers in Germany is based, for the most part, on the conclusions of the Conference of the Ministry of Culture of 2000 and the Framework Agreements of 2000 and 2002. Thus, in accordance with the Framework Agreement of 2000 , the main objective of the training of a preschool teacher is the formation of a highly qualified specialist in pre-school education and education, able to work with children in public and private institutions. The terms of admission remained virtually unchanged in relation to the previous ones, which were issued in 1967 - the age of admission of at least 17 years, the presence of a certificate of completion of high school or vocational training, as well as a certificate of passing a pedagogical practice in a particular kindergarten that is a priority. At the same time, according to the results of the [10], the structure of training, which has grown from two to five years of study with compulsory practical training in various socio-pedagogical spheres of activity, has changed considerably. The content of curricula with compulsory subjects (pedagogy, psychology, children's literature, social hygiene, jurisprudence) was enriched by the educational thematic areas: communication and society, socio-pedagogical theory and practice, musical aesthetic creativity, ecology and health, organization, jurisprudence and management, religion / ethics in accordance with the law of the land, etc. The model of training involves different types of practice, an increase in the academic load (up to 3.600 hours); the division of exams into two parts [10].

The Framework Agreement of 2002 introduced changes to the goal of vocational training, which at the present stage requires the development of the ability to implement educational, educational tasks and the implementation of independent childcare in any social-pedagogical field; promotion of professional competence development, formation of professional, professional and social competencies; qualification only upon completion of higher education [10].

A major shift in Germany's state regulation towards improving the training of preschool teachers was standardization, which, despite the administrative diversity of federal lands, ensured the uniformity of the requirements for the professional competence of preschool teachers. The 
list of competencies and standards that have been written in courses in curricula and programs is correlated with the competencies presented in the standards and pedagogical training requirements developed by the Mixed Commission for Teacher Education in October 2000 [11] and implemented on the basis of the reform of December 16, 2004 - "Teacher Education Standards: Teacher Education", which became one of the most important reforms in the pedagogical education of Germany. The provisions of the document regulated the main professional competencies of teachers, which had to be observed throughout the territory of the Federal Republic.

In the document "Standards for teacher training: pedagogical industry" it was noted that the Permanent Conference of the Ministry of Culture considers the central task of ensuring the quality of school and other types of education. An important element in the realization of this task and the development of the entire education system is the introduction of standards and control over their compliance.

\subsubsection{France}

In general, the pre-school teacher training in France, according to the results of a study by the Organization for Economic Cooperation and Development, is determined by the highest quality among the countries of Western Europe [12]. So, only in France, the professional training of a preschool teacher in terms of value equates to the professional training of primary and secondary school teachers; only in France a clear priority has been given to obtaining university teaching education (in Germany, higher professional schools, pedagogical institutes, in the UK professional schools, higher vocational schools, institutes, colleges, universities). Despite the coherent system of vocational training, the availability of flexible mechanisms for the training of preschool education professionals, French experts in preschool education and academics are concerned about the fact that teachers of pre-school establishments prepare to work with preschool children according to the model of the school system and explain this by the 1991 reform - 92 years old. Scientists argue that while integrated training contributes to the coherence and continuity between pre-school and primary education and educates unified and universal educators, the opportunity to provide adequate practical training for preschool education teachers, which does not involve the organization of education, and the organization of the child's development environment and leisure. This means that the content of pre-school education from two years is formed by a disciplined-oriented approach (eg, French, mathematics, computer science) inherent in elementary school, but this approach is not correct in pre-school education, where the educational process is carried out within the framework of an interdisciplinary approach. In addition, the practice during the basic training of future teachers in preschool institutions is an essential element in the development of professional competence. Experts emphasize that the training of future preschool teachers and primary school teachers, which focuses only on "school-oriented learning" of children, depriving future educators of the opportunity to study properly and practice in work with preschool children, will result in the result that pre-school education will lose its developmental function and will become an accompanying element for the elementary school. Compared to some other European countries, for example, in Sweden and Spain, the percentage of future teachers in pre-school institutions in France who received relevant certificates of pre-school education during their studies at a higher educational institution is rather low [13]. Scientists consider the solution to this problem in improving professional standards in accordance with European requirements and in clearly shaping the professional competences of future specialists [14].

\subsubsection{Great Britain}

At the present stage of the professional training of pre-school education teachers in the UK, according to the findings of the team of British experts, there is a fairly small proportion of staff working in pre-school educational institutions who have the relevant profession (only 18 to $20 \%$ of these staff have basic pedagogical education in the necessary direction of professional activities) [15]. In general, pre-school teacher training in the UK is subordinated to institutions such as: Office for Standard in Education (OFSTED); Social Inspection Services (SIC) Social Services Inspection (SS); Teacher Training Agency (TTA); Qualifications \& Curriculum Authority (QCA); National Early Years National Training Organizations (EYNTO); Quality Assurance Agency (QAA) [16].

The major reforms in UK pedagogical education are related to the "Rules for Teaching Education", "Basic Teaching: Program Approvals" and "Basic Teacher Training Reform" documents that identified the state strategy and tactics of teacher training in the country [17]. In general, the formation of the system of pedagogical education in the UK and the system of training preschool teachers, in particular, took place in a radically opposite direction of development than it was in other Western countries, namely continental Europe, where, as a rule, the system develops from centralized education management to decentralized. In the UK, changes have taken place in the direction of complete administrative autonomy [18] to strict regulation, control and monitoring by public authorities [19], at the present stage, autonomy is maintained only in terms of financing [20].

Until the 1930s, the main content of pedagogical education in the United Kingdom was independent education, personal growth, diversity and freedom to choose forms, methods and tools for organizing an open democratic educational process [21]. There was no state-regulated National Curriculum for Professional 
Teacher Education, and university lecturers enjoyed greater autonomy than their counterparts in continental Europe. Teacher education was acquired at universities, polytechnics or colleges of education and had rather free criteria in professional qualifications and specialties. Since the 1970s, such an approach to teacher training has been called into question, and as a consequence, the National Curriculum (National Curriculum) was published in 1988, which identified further transformational changes in the professional-pedagogical education of all teachers in Great Britain. The logical continuation of such changes was an increase in the requirements for the teaching profession as a whole [19], and the Council for Accreditation of Teacher Education (CATE) was founded in 1984, which in 1994 was replaced by the Teacher Training Agency (TTA). The Council, subsequently the Agency, determined the contents of the programs of vocational training of teachers, in which the emphasis shifted from theoretically oriented (pedagogy, psychology, sociology, etc.) [22] to practical-oriented subjects [23]. These changes were not accidental and reflect very precise policies in the field of pedagogical education, initiated by even conservative governments, Margaret Thatcher and John Major, and the further implementation of reforms was carried out by the government of Tony Blair, for the words of which the school 1970-1980 did not meet the new standards of education and were not able to form the competencies required for the labor market [24]. T. Blair argued that: "... education is one of the main priorities of the government. Teaching a profession is crucial for our mission ... The Government's Green Paper sets out proposals for improving the teacher's profession ... These proposals have created the prerequisites for the most fundamental reforms of the pedagogical industry, which are aimed at high-quality state regulation of the system of pedagogical education" [25].

Reforms initiated by the Labor Government contributed to the implementation of the Unified National Curriculum, which was developed since 1988 and which justified the feasibility of centralized state control over the quality of vocational training, and there was a change in the focus of professional training on the process for results. In general, the educational policy was determined by the focus on the unification of professional requirements for teachers, which was manifested in standardization, the definition of precise standards for pedagogical education, in particular the introduction of the Qualified Teacher Status (QTS), which is a kind of official quality certificate of professional teacher's skills All these reforms in the pedagogical education system have contributed to the expansion of the range of opportunities for teaching in the UK. So, according to a study by the European information network on education, "a consistent model is the most common way of obtaining a profession of a teacher ..." From the late 1980s to the early 1990s, a number of alternative ways of pedagogical education and the status of a qualified teacher were formed got the opportunity to receive education, while working part-time. That meant the teacher could study without leaving the work for it within 2 or 3 years. They called these teachers like a practicing one. After providing of alternative ways of pedagogical education, teachers have got the possibility to get the higher professional education and previous pedagogical practice and education was taken into account [25].

On the whole, such radical transformations in pedagogical education and preschool education were aimed at: facilitating better assimilation by the future preschool teachers of basic professional knowledge; Reduce the impact of universities on vocational training through the introduction of alternative vocational training programs; to train teachers of a new class that would effectively organize the educational process and implement well-defined goals [26].

Recent studies convinced of the need for further strategic activity of the state in the direction of improving the system of vocational training of preschool teachers: since the question of the ratio of wages to different qualifications of pre-school teachers and working conditions has not been determined to date, the state directs its activities to develop mechanisms for solving this problem [27]; requires the correction of the content of the curricula of vocational training (the theoretical training of teachers is not fully correlated with the content of preschool education) [27]; out of concern was the issue of developing standards for training on the basis of cooperation with employers and practitioners; The settlement needs a question of the role of preschoolers institutions and their partnerships, in accordance with the latest recommendations of the Ministry of Education with institutions for the training of preschool educators in the UK; in connection with the growing diversity of society in the UK, the prospect sees the need for a broadly profiled staff training for working with immigrant children and their families; development of vocational training programs for postgraduate study [27]; requires the correction of the content of the curricula of vocational training.

The carried out characteristic of the practice of management of professional training of preschool teachers gave the chance to systematize features of educational strategy of development of pedagogical preparation of experts of the specified branch and to allocate common and distinctive signs with the Ukrainian system of pedagogical education (Table 1). 
Table 1. Educational policy in the field of professional training of preschool teachers in Western Europe and preschool education specialists in Ukraine

\begin{tabular}{|c|c|}
\hline Western European countries & Ukraine \\
\hline \multicolumn{2}{|c|}{ value-oriented directions } \\
\hline $\begin{array}{l}\text { readiness to ensure the processes of globalization and informatization } \\
\text { of society, understanding, respect for European legal obligations in } \\
\text { the context of human rights, openness to different cultures, will to } \\
\text { peaceful coexistence, concern for ecological balance in Europe and } \\
\text { the world, readiness to protect freedom, democracy and human rights, } \\
\text { the will to ensure peace }\end{array}$ & $\begin{array}{l}\text { intensive European integration of higher education of Ukraine } \\
\text { into the European educational space, orientation of professional } \\
\text { training to ensure observance of all rights and freedoms }\end{array}$ \\
\hline \multicolumn{2}{|c|}{ institutional priorities } \\
\hline $\begin{array}{l}\text { ensuring the functioning of the system of professional training of } \\
\text { teachers in European countries and providing opportunities for } \\
\text { vocational education in various educational institutions in order to } \\
\text { ensure equal access to high quality education for all those wishing to } \\
\text { join professional activities in the preschool field) }\end{array}$ & $\begin{array}{l}\text { there is a constant process of renewal, expansion, development, } \\
\text { implementation and application of innovative forms, methods and } \\
\text { teaching aids, taking into account the best domestic and foreign } \\
\text { experience of pedagogical education, which will provide quality } \\
\text { and effective formation of professional competence of preschool } \\
\text { teachers }\end{array}$ \\
\hline \multicolumn{2}{|c|}{ system-structural } \\
\hline $\begin{array}{l}\text { adaptation and unification of certain aspects of the functioning of the } \\
\text { system of professional training of teachers in different European } \\
\text { countries, mutual recognition of diplomas, determination of the } \\
\text { content of education, equalization of terms of study and degrees of } \\
\text { education }\end{array}$ & $\begin{array}{l}\text { Ukraine's accession to the Bologna Process provides, } \\
\text { respectively, for the decentralization of institutions providing } \\
\text { professional pedagogical training and the reorientation to a } \\
\text { three-cycle system of professional training (bachelor, master, } \\
\text { doctor) }\end{array}$ \\
\hline \multicolumn{2}{|c|}{ technological and conceptual } \\
\hline $\begin{array}{l}\text { introduction of a multicultural (multicultural) approach, } \\
\text { personality-oriented, competence-based, axiological, acmeological } \\
\text { and practice-oriented approach to research-based education, etc. }\end{array}$ & $\begin{array}{l}\text { introduction of European approaches to professional training of } \\
\text { educators and other employees of the preschool industry, } \\
\text { including: competence, taking into account the acmeological, } \\
\text { holistic approach, reorientation of professional training to } \\
\text { acmeological principles, implementation of personality-oriented } \\
\text { concept in the organization of the educational process }\end{array}$ \\
\hline \multicolumn{2}{|c|}{ strategic } \\
\hline $\begin{array}{l}\text { unification of standards of pedagogical education, their development, } \\
\text { identification of factors, search of mechanisms and principles of } \\
\text { adaptation of standards of pedagogical education to the European } \\
\text { qualification framework for the purpose of strengthening of } \\
\text { communications and establishment of cooperation in the field of } \\
\text { higher education with other European countries }\end{array}$ & $\begin{array}{l}\text { the National Qualifications Framework (NQF) has been } \\
\text { developed, and the reference point for the professional training of } \\
\text { preschool teachers in Ukraine is also the educational and } \\
\text { qualification characteristics (EQF), which are in line with the } \\
\text { National Qualifications Framework; } \\
\text { standards at the present stage are only in the process of } \\
\text { development }\end{array}$ \\
\hline
\end{tabular}

Source: systematized by the author

The generalized strategic objectives of educational policy presented in comparative table 1 show that in Ukraine the following areas need to be finalized: regulatory framework aimed at reorienting higher education, entering not only the European educational space with regard to informatization, but also the global space, which provides for the strengthening of the principle of "open society", tolerance, multicultural orientation of professional training for peaceful coexistence; needs normative and legal improvement of the issue of expansion and variability of professional training of the network of educational institutions that provide professional training of preschool teachers; the question of the mechanisms of recognition of scientific degrees remains open, the standards remain undeveloped.

Therefore, in our opinion, the experience of Western European countries in regulating the processes of reforming the professional training of preschool teachers will be valuable in the context of the implementation of the tasks and main provisions of the Bologna Declaration in
Ukraine. Thus, to ensure the process of unification of professional requirements for preschool teachers, harmonization of management principles of pedagogical education, transition to a two-phase system of professional-pedagogical training, organization of two consecutive stages of training in commensurate terms, a number of laws and regulations were adopted in Western Europe.

\subsection{Characteristics of Qualifications Requirements to Preschool Teachers in Western European Countries}

\subsubsection{France}

It should be noted that before 1991-1992, the training of preschool teachers working in "maternity schools" was carried out according to separate programs, different from the programs of vocational training of primary school teachers. After receiving a certificate of secondary education, entrants who intended to receive the profession 
of a preschool teacher enrolled in courses of 2 years of professional training for ordinary career-oriented colleges. After successful completion of such colleges, graduates had the right to work only in the field of preschool education.

"Teacher training is key to success in education," says French education minister Najat Vallaud-Belkacem. "All modern studies prove that the progressive professional development of a student depends to a large extent on the professionalism of the teaching staff. Composition, therefore, the quality of teaching teachers in higher education is the quality of training a teacher who works in the field of pre-school, secondary or general education. That is why the training of teachers from different parts has such an important place in the school reform program" [28].

From 2010-2011, the issue of the qualifications of teaching staff working in the field of pre-school education acquired a new stage of development, and the result of reforms in the system of preschool and pedagogical education in France was the requirement to obtain a master's degree in professional activities in pre-school institutions [29]. Only a bachelor's degree was required for a specified period. The reforms introduced in the 2010/2011 academic year, aimed at standardizing and professionalizing the training of teachers in France, contributed to the introduction of the educational qualification level "Master". At the same time, there are still contradictions between academic and professional training [30].

\subsubsection{Great Britain}

Since the 1980s, several educational reforms have been initiated in the UK aimed at developing qualifications of graduates in specialties related to the pre-school sector. Among such reforms is the introduction of compulsory Early Childhood Studies Bachelor Degrees and National Professional Qualifications at the Joint Leadership Center (NPQICL) to support the leaders of children's centers.

The introduction of the EYPS status, which is one of the four models of professionalization and career development in the United Kingdom, is considered an important stage in educational policy and has contributed to the European level in this area of pre-school teacher training. Such changes have intensified the professional training of pre-school workers in the UK, who had already worked in the system of pre-school education, education, and care. As of 2011, about 10,000 practicing teachers and practitioners were involved in the process of professional certification in order to obtain the status of a professional in preschool education, which is achieved through the combination of formal training and assessment of practical activities by involving one of four models of professional training of teachers in the Great Britain Applicants who qualify for the status of a pre-school education professional must demonstrate that they have mastered all 39 standards of professional training [31].

At the present stage, the creation of the Council for the Accreditation of Teacher Education (CATE) was an important step towards improving the content of teacher training in the United Kingdom, with the creation of which the process of regulation and streamlining of training courses began within the framework of basic pedagogical training in the country. With the help of RAPO and the inspection service, the government carries out accreditation of courses, exercising control over the curriculum, requirements for the development of courses, number of hours, etc. The research in [17] shows, that in this way the implementation of the standardization process of vocational and pedagogical training in the United Kingdom is carried out. As in Germany and France, standardization in Britain causes ambiguous reactions among researchers, because in the programs and curricula, according to the requirements of the state, not only the content of normative disciplines is regulated, but also their duration and peculiarities of obtaining qualification [17].

The standardization of pedagogical education positively influenced the quality of not only vocational training of teachers but also the quality of educational services at different levels of education [11]. The first advantage of implementing the standards of pedagogical education was that they became a comprehensive description of the complex of professional duties and the necessary competences of teachers in a clear outline of specific terms that characterize qualifications and professional responsibilities. The standards contributed to the systematization and the hierarchy between the first and second stages of university pedagogical education. The standards defined competence and competence of teachers who must be formed at different stages of vocational training. The second advantage of the standards of pedagogical education is that their introduction contributed to the further development of the function and professional duties of teachers (control over professional development and development, promoting the development of an educational institution in which the teacher works, etc.).

Characteristics of qualifications requirements for preschool teachers in western European countries are allowed to present the comparative table of their common and different aspects (Table 2). 
Table 2. Features of qualifications in Western Europe and Ukraine

\begin{tabular}{|c|c|}
\hline Preschool teachers qualifications in Western Europe & $\begin{array}{l}\text { Preschool teachers qualifications in } \\
\text { Ukraine }\end{array}$ \\
\hline $\begin{array}{l}\text { Germany } \\
\text { Employee of a preschool educational institution (Youth / Child Care Worker); } \\
\text { Childcare Workers; } \\
\text { State-approved Child Care Specialist; } \\
\text { Educator of the House of Pestalozzi-Frobel-Haus; } \\
\text { State Recognized Educator; } \\
\text { State-recognized teacher of the Academy of Special Education and Social Work (Teacher } \\
\text { Specialized Academy for Educational Social Work); } \\
\text { Teacher of the School of Special and Social Education (State Registered Educator Specialized } \\
\text { School for Social Pedagogic); } \\
\text { State Accredited Teacher; Social Recognized Social Educator; } \\
\text { Social pedagogue of the State Technical College of Social Education; } \\
\text { State-recognized preschool teacher, educator (State Recognized «Erzieher» (Educator/Early } \\
\text { Childhood Educator)) } \\
\text { France } \\
\text { "Preschool teacher" (Éducatrice / éducateur de jeunes enfants); } \\
\text { "School teacher" or "school teacher" (Professeur de écoles); } \\
\text { Preschool teachers-pediatricians (Puéricultrices - pediatric nurses, pediatricians); } \\
\text { Agents of territorial preschools (Agent territorial specialisé des écoles maternelles); } \\
\text { Babysitters for day care for children (assistantes maternelles); } \\
\text { For the field of postgraduate education in France prepare "instructors of pedagogical staff" } \\
\text { United Kingdom } \\
\text { Early years teacher with QTS status; } \\
\text { Early and Professional Preschool Teacher with Early Years Professional with EYP status; } \\
\text { Early preschool child care teacher with different job titles: child nurses / child care teachers, } \\
\text { assistant workers, accompanying teachers, etc.); }\end{array}$ & $\begin{array}{l}\text { Educator; } \\
\text { Educator of a preschool educational } \\
\text { institution; } \\
\text { Educators-methodologists of preschool } \\
\text { educational institution; } \\
\text { Director (Head) of a preschool } \\
\text { educational institution; } \\
\text { Director of the educational complex } \\
\text { "Preschool educational institution - } \\
\text { general educational institution" }\end{array}$ \\
\hline
\end{tabular}

The variability of qualifications in Western Europe is very wide and is due to the specifics of the work and functional responsibilities of preschool teachers, while in Ukraine according to the Order "On approval of educational and qualification characteristics of scientific and pedagogical staff" the list is represented by only five qualifications with their descriptors, as shown in the comparative table "Features of the names of qualifications in Western Europe".

Thus, it will be promising to expand the list of qualifications of preschool education workers in Ukraine, taking into account Western European qualifications, which are characterized by a wide range and variability. In addition, it is important to form different descriptors (descriptions) of these qualifications, taking into account the domestic traditions of professional training of preschool teachers, as recourse to the experience of developing qualifications will ensure the implementation of the European concept of "broad access to vocational education for all" in Ukraine.

\subsection{Characteristics of Modern Preschool Teachers' Professional Education System Functioning in Western European Countries}

\subsubsection{Germany}

In general, education policy in Germany in the field of pedagogical education can be represented in two stages:
- the first, so-called "umbrella", for professional-pedagogical education, was the introduction of standards;

- $\quad$ the second - "professionalization", which included the direction of professional training for the specification of professional competences and continuous professional training [32].

The functioning of the system of vocational training of preschool teachers in Germany at the present stage is characterized by tendencies of integration into the European educational space, which manifests itself in the following aspects: at the strategic level - the priority of vocational training of a preschool teacher is the formation of a highly qualified competent specialist in pre-school education and upbringing able to work with multinational contingents. children (gifted children, children with special needs, children of immigrants, refugees, children from incomplete ones and dysfunctional families, etc.) in different type (traditional preschool education institutions, convenience orphanages, rehabilitation centers and centers of primary and preschool education, etc.) and ownership (state, municipal, public and private) kindergartens); at the functional level - an increase in the period of education for preschool teachers (modern training for "bachelor" involves at least four or five years of study at a higher school or university respectively and obtaining a minimum level of professional competence as a graduate); the state provides and supports student mobility within the various higher educational institutions of the country and the EU; 
expanding educational services for the benefit of students; at the contextual level - the content of pre-school teacher training programs in Germany, depending on educational policy, and based on the Resolutions of the Standing Conference of the Ministers of Culture of the federal states "General State Requirements for the Common Content of Case Studies and Content of Vocational Training in Teacher Training" is constantly expanding, the shift of emphasis is in the direction of practical training.

\subsubsection{France}

The application of functional analysis of the system of vocational training of preschool teachers in France allowed to generalize the following general tendencies of its development at the present stage: at the strategic level creation of conditions and provision of multifunctional pedagogical education that is capable of responding to dynamic changes in the development of society and its requirements; at the functional level - the constant development and transformation of the network of educational institutions for the training of preschool teachers with the aim of obtaining university-level teaching staff - Universities (1989) and subsequently Higher Schools for Education Professionals (2013); creation of flexible mechanisms for vocational training and education of a preschool teacher (integrated system of vocational training of preschool teachers and primary school teachers); the tendency to increase the period of vocational training (five years of study in high school) and increase the requirements for qualification (priority is recognized by the master's educational level of preschool teachers, at the contextual level - the contents of the programs of the French system of vocational training of preschool teachers is constantly dependent on the concept of preschool education ; the gradual implementation of the conceptual provisions of the concept of "continuous learning" - the development of mechanisms for transforming auxiliaries and parenting pediatricians (puériculture) and the acquisition of their qualified education by a preschool teacher, the opportunity for teachers of pre-school children (jeunes enfants) to qualify elementary school teachers (éducatrices) and vice versa; in the education sector of "maternal schools" (école maternelle), the transformation of the vocational training of these qualifications of the director of an educational institution (conseilleres pédagogiques) or inspectors.

\subsubsection{Great Britain}

The development of the early childhood education and care (ECEC) system in the United Kingdom (as in the case of England) dates back to the mid-1990s. The directions of educational policy in this area of pedagogical training included: a). the introduction of the Integrated Qualifications Framework (IQF) or the literally Integrated Qualification Framework, the purpose of which is to establish a structure of equivalence of qualifications for all occupations associated with the system of preschool education;

b). the introduction of the status of a qualified preschool teacher or more closely to the contents - Early Years Professional Status (EYPS).

The analytical review showed that governmental management is the tool for regulations and improvement of teachers' higher educational system and determines its reformation, thus it can be viewed as the perspective direction of improvement of the teaching education policy and effective tool of its development.

Due to legislative initiatives in the field of professional training of preschool teachers, the terms of professional training, educational degrees and qualifications have also changed.

The terms of professional training for obtaining one of the two main educational degrees "bachelor" and "master" have the following limits: training for a bachelor's degree in Western Europe is from 3 to 4 years on a full-time basis, and from 3- $x$ to 6 - in absentia; obtaining a master's degree, depending on the direction is calculated from 1 to 1.5 years, if the master's degree is professional and from 1.5 years to 2 years in research-oriented education. Addressing the issue of terms of professional training of employees of preschool educational institutions in domestic universities, it should be noted that bachelor's education in Ukraine is obtained within four years, if the entrant "came from school", and from 1.5 to 2.2-2.5 years, if it is a graduate of a college or pedagogical school.

As for the network of educational institutions for preschool teachers, we can also present it in the form of a comparative table (Table 3 ).

Promising further development is the expansion of the network of educational institutions for preschool education workers in Ukraine with alternative existing institutions. For example, prototypes of German professional or vocational schools of social pedagogues (technical schools of social pedagogy); technical schools, higher vocational schools, higher pedagogical schools, vocational training and retraining centers, transcultural pedagogy centers typical of Western Europe, regional vocational academies in social pedagogy, private correspondence schools. It is possible to follow the analogy of the French experience and unite all educational institutions for the professional training of preschool teachers into one large conglomerate, as a generating center of advanced pedagogical ideas, which uniformly regulates the system of professional-pedagogical education. British university-type schools are interesting for borrowing. 
Table 3. Network of vocational training institutions for preschool teachers in Western Europe and Ukraine

\begin{tabular}{|c|c|}
\hline Western European countries & Ukraine \\
\hline $\begin{array}{l}\text { Germany: vocational colleges and schools, gymnasiums, higher pedagogical schools equivalent to } \\
\text { universities, pedagogical institutes, vocational academies and universities; } \\
\text { France: pedagogical colleges, university-type institute for teacher training; } \\
\text { United Kingdom: institutes, colleges, research institutes and universities, university-level colleges, } \\
\text { Department of Higher Education Innovation and Qualifications, } \\
\text { Germany: advanced training centers (pedagogical centers), regional vocational academies in social } \\
\text { pedagogy, Wilhelm Buchner Private Correspondence School in Darmstadt, German Institute of } \\
\text { Correspondence Courses, city teacher training institutes; } \\
\text { France: higher education institutions for the training of education professionals, institutes of } \\
\text { additional pedagogical education and the National Center for Pedagogical Documentation, } \\
\text { Regional Centers for Pedagogical Documentation; } \\
\text { Great Britain: institutes, research institutes and universities }\end{array}$ & $\begin{array}{l}\text { Pedagogical schools and colleges, } \\
\text { institutes, universities, institutes of } \\
\text { advanced training, institutes of } \\
\text { postgraduate education } \\
\text { educational and research institutes, } \\
\text { centers of advanced training, centers } \\
\text { of practical training }\end{array}$ \\
\hline
\end{tabular}

Source: systematized by the author on the basis of the analysis of features of functioning of systems of professional pedagogical preparation of personnel of preschool education in the countries of Western Europe and Ukraine

Comparative analysis of administrative management, network of educational institutions, qualification requirements and names of specialties allow to determine the prospects of professional pedagogical education in the direction of building effective management interaction between structural components, to expand the list of educational institutions that can provide vocational education not only within higher education institutions. . Thus, the analysis of the functioning of the system of professional training of preschool teachers in Western Europe revealed that it is decentralized in Germany, due to the administrative structure of the country, but at the national level is determined by the Permanent Conference of the German Ministry of Culture in the field of education and culture.

Based on the comparative analysis presented in Table 1, 2,3 , it should be noted that the system of professional training of preschool teachers for France, Great Britain and Ukraine is characterized by the traditional centralized interaction between government agencies and educational institutions providing professional training. The domestic system of professional pedagogical education is characterized by a trend of decentralization, which is reflected in the new version of the Law "On Higher Education" of July 7, 2014 [33]. As already it was mentioned, there is a limited and narrow network of educational institutions that provide training for preschool teachers in Western Europe and Ukraine, however, common is the functioning of higher education institutions - colleges, institutes, universities, urban institutes of postgraduate education, institutes

\section{Conclusions}

The investigation of the progressive practices of preschool teachers' professional training in Western European countries made it possible to distinguish the directions of Western European countries' experience implementation into the Ukrainian higher pedagogical education system. These directions are divided into three levels of improvement: governmental, institutional and procedural.

At the governmental level, the improvements are required systematic changes in the development of comfortable decentralization mechanisms for universities autonomy-government. From the experience of the countries of Western Europe, it is possible to distinguish the adoption of new statutes of higher education institutions, the creation of independent associations and professional associations at universities, carrying out expert activities in different areas of pre-service teacher education, conduct objective independent research, develop educational and scientific- research projects, search for professional and financial (to provide patronage funding for the project or research) partners. Positive experience is also seen in the mutual recognition of diplomas at the inter-university level to increase the academic mobility of students.

At the institutional level, there is the necessity which is an extension of the network of higher education institutions and other educational institutions providing vocational training for pre-school teachers in Ukraine. In this case, the actual experience of the countries of Western Europe is determined to provide wide opportunities for obtaining both elementary and basic professional pedagogical education in the field of preschool education in the course of education in vocational schools, higher pedagogical schools, high schools, technical schools, special schools, technical and social higher schools, vocational training centres at universities and regional vocational training centres, etc.

At the procedural level, work should be focused on the building of conditions for quality basic education in the context of the Bologna three-cycle training of bachelors, masters and doctors, which is concerned to the removal of the "specialist" from the initial plans of the educational degree. This means that basic graduate education of a bachelor should fully provide professional preparation for successful teaching activity in the pre-school system.

Within the procedural approach, the Ukrainian universities should work in the directions of rethinking of continuous professional development of teaching staff. The quality of services and the level of professional 
competence of pre-school teachers depend not only on the consequences of individual basic training. Diversification and implementation of Western European countries' innovative forms of professionalization provide positive results in further formation and improvement of professional competence of preschool educators: short-term retraining without in-production (eg. specialized or direct vocational training, coaching); several weeks of training in the format of the Union of Practitioners. Involving practitioners in direct research and project development can significantly increase the outcome of their professional activities. Direct professional activity and work in professional development centers on the basis of individual educational institutions can also be a positive experience. Particularly positive is the practice outside the country or region, which is implemented in the countries of Western Europe by state funding for foreign travel of preschool workers.

The good practice is seen in the introduction of the Integrated Qualifications Framework and the status of a qualified preschool teacher or more closely to the contents - Early Years Professional Status etc.

The investigation of preschool teachers' professional training in Western European countries and identification of fragments of perspective experience for implementation into Ukrainian higher pedagogical system forms the basis for the development of The Conception of preschool teachers' professional training in Ukraine. The content of the Conception is regarded to be presented in the further issues dedicated to the problem of preschool teachers' professional training improvement as not all aspects of positive Western European experience were presented in this article. Thus, the organisational and methods aspect requires the comparative analysis and distinguishing of positive practices implementation and European conceptual basis of preschool teachers training should be also analysed from the perceptive of adaptation to Ukrainian pedagogical education dimension, which builds the next issue aim.

\section{REFERENCES}

[1] M. Friedman, and M. Kuznets. Income from Independent Professional Practice, National Bureau of Economic Research, Vol. 194, pp. 81-94, 2014.

[2] Rethinking education: towards a global common good? UNESCO, 2015. Retrieved from https://unesdoc.unesco.org /ark:/48223/pf0000232555

[3] Revolutionary patterns of education Russia: from tsarism to communism. Encyclopcedia Britannica. Retrieved from https://www.britannica.com/topic/education/Revolutionarypatterns-of-education\#ref47687

[4] Other European countries. Encyclopcedia Britannica. Retrieved from https://www.britannica.com/topic/education
/Other-European-countries

[5] N. Melnyk, N. Bidyuk, A. Kalenskyi, B. Maksymchuk, N. Bakhmat, O. Matviienko, T. Matviichuk, V. Solovyov, N. Golub, and I. Maksymchuk. Models and organisational characteristics of preschool teachers' professional training in some EU countries and Ukraine, Zbornik Instituta za pedagoska istrazivanja, Vol. 51, No. 1, pp. 46-93, 2019. https://doi.org/10.2298/ZIPI1901046M

[6] N. Melnyk. Theoretical and methodological foundations of professional training of preschool teachers in the countries of Western Europe, Doctoral dissertation, Uman State Pedagogical University, Uman, Ukraine, 2017.

[7] I. O. Stashevska. Problems in using the methods of scientific knowledge, 2016. Retrieved from http://www.nbuv.gov.ua/ old jirn/Soc_Gum/pspo/2012 36_1/stashevs6ka.pdf

[8] I. Sokolova. Scientific approaches to conducting comparative studies in education, Educational science = Oświatologia, Vol. 3, pp. 23-29, 2014.

[9] B. Wulfson, and Z. Malkova. Comparative pedagogy: history and contemporary problems. URIE, Moscow, 2003.

[10] O. Sulyma. Professional training of preschool teachers in the higher education system of the Federal Republic of Germany. NAPN Ukraine, Kyiv, 2015.

[11] H.-G. Kotthoff, and E. Terhart. Teacher Education in Germany: Traditional Structure, Strengths and Weaknesses, Current Reforms, Scuola democratica, Vol. 3, pp. 1-10, 2013.

[12] Starting Strong: Early Childhood Education and Care. OECD, Paris, 2001

[13] F. Rosenwald (ed.) Repères et références statistiques sur les enseignements, la formation et la recherche [Benchmarks and statistical references on lessons, training and research]. DARES, Paris, 2005.

[14] Fenêtre sur Cours, No. 229 [Window on course, No. 299]. SNUipp, 2002.

[15] P. Moss. Renewed Hopes and Lost Opportunities: early childhood in the early years of the Labour Government, Cambridge Journal of Education, Vol. 29, No. 2, pp. 229-238, 1999.

[16] Briefing of (UNESCO) field staff. UNESDoc, 1970. Retrieved from http://unesdoc.unesco.org/images/0000/000008/0 00816EB.pdf

[17] L. Pukhovska. Teacher training in Western Europe: community and disagreement. Higher School, Kyiv, 1997.

[18] Resolution concerning updating the International Standard Classification of Occupations. Retrieved from http://www.ilo.org/public/english/bureau/stat/isco/docs/resol08.p df

[19] G. Ostinelli. Teacher Education in Italy, Germany, England, Sweden and Finland, European Journal of Education, Vol. 44, No. 2(2), pp. 291-308, 2009.

[20] V. Halstead. Teacher Education in England: Analysing change through scenario thinking, European Journal of Teacher Education, Vol. 26, No. 1, pp. 63-75, 2003.

[21] A. Hargreaves. Teaching in the Knowledge Society: 
Education in the Age of Insecurity. Teacher College Press, New York, London, 2003.

[22] B. Moon. Teacher in England: Current Models and New Developments. In Institutional Approaches to Teacher Education within Higher Education in Europe: Current Models and New Development (Editors: B. Moon, L. Vlasceanu, and L. Conley Barrows), UNESCO-CEPES. Bucharest, pp. 67-84, 2003.

[23] P. Stephens, F. Egil, and C. Kyriacou. Teacher training and teachereducation in England and Norway: a comparative study of policy goals, Comparative Education, Vol. 40, No. 1, pp. 109-130, 2004.

[24] G. Whitty, L. Barton, and E. Barrett. Teacher Education and Teacher Professionalism in England: some Emerging Issues, British Journal of Sociology of Education, Vol. 15, No. 4, pp. 529-543, 1994.

[25] J. Furlong. New Labour and teacher education: the end of an era, Oxford Review of Education, Vol. 31, No. 1, pp. 119-134, 2005.

[26] National Foundation for Educational Research. Compulsory age of starting school in European countries. NFER, Slough, 2013.

[27] Early Childhood Education and Care Policy in the United Kingdom. $\quad O E C D, \quad 2000 . \quad$ Retrieved from http://www.oecd.org/unitedkingdom/2535034.pdf
[28] Teacher Training Key in Education Reform Implementation, 2015. Retrieved from http://www.education.gouv.fr/cid97738/ teacher-training-key-education-reform-implementation.html

[29] The European Higher Education Area in 2015: Bologna Process, Implementation Report. EURYDICE, 2015. Retrieved from https:/eacea.ec.europa.eu/national-policies/eurydice/conten t/european-higher-education-area-2015-bologna-process-im plementation-report_en

[30] E. Fraisse. Regards sur la formation des maîtres en France [Insights into teacher training in France], Revue Internationale d'éducation de Sèvres, Vol. 55, pp. 61-72, 2010.

[31] M. Urban, M. Vandenbroeck, A. Lazzari, K. Van Laere, and J. Peeters. CoRe: Competence Requirements in Early Childhood Education and Care. University of East London, Cass School of Education, London; University of Ghent, Department for Social Welfare Studies, Ghent, 2011.

[32] D. Bosse. Zur Situation der Lehrerbildung in Deutschland [The situation of teacher training in Germany]. In Reform der Lehrerbildung in Deutschland, Österreich und der Schweiz [Reform of teacher training in Germany, Austria and Switzerland] (Editors: D. Bosse, L. Criblez, and T. Hascher). Prolog-Verlag, Immenhausen, pp. 11-28, 2012.

[33] Law of Ukraine No. 1556-VII: About higher education. Legislation of Ukraine, 2014. Retrieved from http://zakon5.rada.gov.ua/laws/show/1556-18 